International Journal of Instruction

e-ISSN: 1308-1470 • www.e-iji.net
July $2019 \bullet$ Vol.12, No.3

p-ISSN: 1694-609X

pp. 219-238

Received: 19/11/2018

Revision: 28/05/2019

Accepted: 04/06/2019

OnlineFirst:05/08/2019

\title{
Critical Thinking Skills, Critical Reading and Foreign Language Reading Anxiety in Iran Context
}

\author{
Mojtaba Aghajani \\ Khatam Ol-Anbia University, Tehran, Iran.mojtaba_aghajani45@yahoo.com
}

Emad Gholamrezapour

Vali-e-Asr University, Rafsanjan, Iran, e.gholamrezapour91@gmail.com

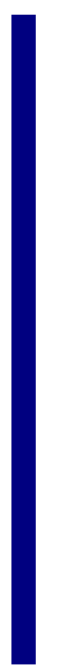

Critical thinking is crucial to the learning process, cognitive development, and effective information seeking. People can use critical thinking skills to understand, interpret, and assess what they hear or read in order to formulate appropriate reactions or responses. The present study intends to investigate the predictive power of critical thinking skills on critical reading and foreign language reading anxiety of Iranian intermediate EFL learners. To this end, 177 intermediate adults male Iranian EFL learners from Khatam ol-Anbia university took part in the study by completing Michigan test of English language proficiency, the California critical thinking skills test, Critical reading scale and foreign language reading anxiety scale. Using KR-21 and Cronbach's Alpha, the reliability of questionnaires was re-estimated. Data were analyzed through multiple regression analyses. The results of multiple regression indicated there was a statistically significant predictive of critical thinking skills. Additionally, Results indicates that a negative relationship between critical thinking skills and foreign language reading anxiety exists as measured by FLRAS. The quantitative findings gathered through CTS and FLRA scales suggest that when there is an increase in CTS of the students, FLRA decreases and vice versa.

Keywords: critical thinking skills, critical reading, foreign language reading anxiety, EFL learner, learning

\section{INTRODUCTION}

There are many contributing factors in the process of learning a foreign language. Some students learn a new language more quickly and easily than others. This simple fact is known by all who have themselves learned a second language or taught those who are using their second language in school. Clearly, some language learners are successful by virtue of their sheer determination, hard work and persistence. These factors can be broadly categorized as internal and external. Internal factors are those that the individual

Citation: Basri, H., Purwanto, As'ari, A. R., \& Sisworo. (2019). Critical Thinking Skills, Critical Reading and Foreign Language Reading Anxiety in Iran Context. International Journal of Instruction, 12(3), 219-238. https://doi.org/10.29333/iji.2019.12414a 
language learner brings with them to the particular learning situation such as: age, personality, motivation (internal), experience, cognition, and native language. External factors are those that characterize the particular language learning situation such as: curriculum, instruction, motivation (external), culture, social status, and access to native speakers (Lightbown, Pasty \& Spada, 2013).

\section{Critical Thinking Skills}

Critical thinking has been one of the hottest issues since the times of ancient Greece. Over the past few decades, many definitions of critical thinking have been offered, but there is no consensus on its definition. As Mason (2007) rightly claims, many philosophers have developed theories of critical thinking. Ennis (1996) argues that critical thinking comprises particular skills such as being able to assess reasons appropriately, or to identify false arguments. Dewey (2001) views critical thinking as a method of intelligent learning that employs and rewards mind. According to Astleitner (2007), critical thinking is a higher-order thinking skill which includes evaluating arguments, and is a purposeful, self-regulatory judgment which ends in interpretation, analysis, evaluation, and inference. Paul and Elder (2007) maintain that critical thinking is the disciplined art of verifying that can be used as the best thinking a person is able to in any system of conditions.

As to the importance of critical thinking, Levine (2002) states that experience may be a great teacher, but it cannot teach us much; just some repeating experiences and happenings. We learn only when we use our creativity, and it happens when we think about our experiences more than only experiencing them. In other words, thinking is very important and has impact on every aspect of our life. In much the same vein, Weiler (2004) acknowledges that critical thinking is crucial to the learning process, cognitive development, and effective information seeking.

Paul and Elder (2002) hold that developing critical thinking is a progressive process which requires hard work, and becoming an excellent thinker is not possible by just taking a beginning course. So, the crucial characteristics of a critical thinker demand a long-lasting period of development. Furthermore, Paul and Elder (2005) give four reasons why critical thinking is becoming more and more important: "accelerating change, intensifying complexity, escalating interdependence, and increasing danger"' (p.12). Moreover, Hale (2008) states that critical thinking can penetrate every aspect of human life if it is substantively conceived and engaged. He emphasizes the importance of critical thinking in education and claims that critical thinking and education are interrelated and inseparable.

\section{Critical Reading}

Reading is a deliberate process undertaken in human communication to reduce ambiguity about connotations a given text expresses; it also includes the conciliation of open and hidden meaning between the text and its reader. Reading is a mental process for interpreting symbols (Chang, 1983). According to Anderson (2003), "reading is an active, fluent process which involves the reader and the reading material in building 
meaning". Crystal (2007), likewise, points out that reading "crucially involves appreciating the sense of what is written:

We read for meaning".

Reading comprehension refers to the understanding of our conclusions after the negotiations of meaning between a text and the reader and involves the assimilation and interpretation of both existing and external schema (Rayner, Foorman, Perfetti, Pesetsky, \& Seidenberg, 2001). Critical reading refers to an awareness of the fact that all texts are crafted objects, written by persons with particular dispositions or orientations to the information, regardless of how factual or neutral the products may be (Freebody $\&$ Luke, 1990). Critical reading is conceived of as active reading, requiring an activity on the part of the learner (Schwegler, 2004). As a matter of fact, critical reading suggests more than the ability to understand the explicit meaning of the passage. In addition, it involves application, analysis, evaluation and imagination. Enhanced critical reading skill has recently been called for in a variety of contexts including educational (Huijie, 2010), advertising (Pirozzi, 2003), media (Millan, 1995), among others.

\section{Foreign language reading anxiety}

Anxiety, a complicated phenomenon, is a kind of emotion. The issue of anxiety in second language (L2) learning has concerned language educators and researchers for many years. A substantial amount of research has been conducted in this area and suggests that anxiety is an important factor in second language acquisition ( $\mathrm{Na}, 2007$; Wei, 2007). Language learning anxiety was - until quite recently - normally associated with productive skills. Today, there is an increasing recognition of anxiety in receptive skills; that is, reading and listening. One of the relatively less-explored types of anxiety is reading anxiety - a specific phobia, a situational type and an unpleasant emotional reaction toward reading which has physical and cognitive reactions.

Of the four skills, reading can be regarded as especially important because reading is assumed to be the central means for learning new information (Grabe \& Stoller, 2001). When L2 readers read second language texts, they try to decode unfamiliar scripts, writing system, and cultural materials. If encountering difficulty in processing them, they may get frustrated with reading, and experience anxiety. Freese (1997) points out that some students encounter problems when reading. They read the paragraphs in the text but are still unaware of what they have read. Saito, Horwitz, and Garza (1999) showed that reading is an important source of input; however, it is also an anxiety provoking activity.

\section{Statement of the problem}

From an educational perspective, there is a general agreement among scholars and researchers on the importance of raising students' critical awareness in schools and in the classroom. Many of them have found significant relationships between critical thinking and academic achievement (Giancarlo \& Facione, 2001; Jacobs, 1995; Villavicencio, 2011; Yeh \& Wu, 1992). Jacobs (1995), for example, made use of the California Critical Thinking Skills Test (CCTST) in order to examine the role of critical 
thinking in private university students' scores on the Student Aptitude Test (SAT). The results indicated that CCTST scores were strongly related to students' verbal intelligence as measured by the SAT. In another study, Villavicencio (2011) studied the relationship between critical thinking and achievement among 220 engineering students. It was found that critical thinking was significantly positively correlated with students' final grades. Moreover, Yeh and Wu (1992) investigated the relationship between critical thinking and elementary and secondary school students' academic achievement. They employed the Cornell Critical Thinking Test, Level X (CCT-X) for measuring critical thinking, and found that scores from this test correlated significantly with students' total achievement scores. In a similar vein, McCutcheon et al. (1992) explored the relationship between critical thinking skills and academic achievement among 60 psychology students. The results of their study revealed that two subscales of WatsonGlaser Critical Thinking Appraisal (WGCTA), i.e. the ability to draw valid inferences and the ability to weigh and interpret evidence, were predictors of higher achievement scores.

\section{Significance of the study}

Critical thinking is an important requirement for successful academic study in the success in education (Giancarlo \& Facione, 2001). Critical thinkers must engage in highly active listening and reading (Elder \& Paul, 2006) to further their critical thinking skills. People can use critical thinking skills to understand, interpret, and assess what they hear or read in order to formulate appropriate reactions or responses. These skills allow people to organize the information that they hear and read, understand its context or relevance, recognize unstated assumptions, make logical connections between ideas, determine the truth values, and draw conclusions (Flemming, 2011). Conversely, engaging in focused, effective listening and reading also allows people to collect information in a way that best promotes critical thinking and, ultimately, successful communication.

\section{Research Questions}

The purpose of the present study is to answer the following research questions:

RQ1: Which subscale of critical thinking skills is a stronger predictor of EFL learners' critical reading?

RQ2: To what extent critical thinking skills can predict foreign language reading anxiety?

\section{LITERATURE REVIEW}

\section{Critical Thinking Skills}

Research on critical thinking in relation to second language learning is still in its infancy. Most of the studies done have been triggered by the claim made by some western scholars who have gone to the extreme of taking a universalist stance claiming that Asian students are deficient in critical thinking abilities. Scholars such as Fox (1994) and Atkinson (1997) consider critical thinking as a form of western cultural 
thinking and hold that Asian students are not able to think critically because such thinking is a form of cultural thinking that is alien to Asians.

Critical thinking is claimed to be important in the acquisition of language skills particularly writing and reading (Elder \& Paul, 2006). Rashid and Hashim (2008) aimed to investigate the relationship between critical thinking and language proficiency. They administered the Cornell Critical Thinking Test (CCTT) and English language proficiency test to 280 undergraduate students of University Utara Malaysia (UUM). The results indicated that there was a significant correlation between critical thinking ability of Malaysian students and their English language proficiency.

Kamali and Fahim (2011) investigated the relationship between critical thinking ability, resilience and reading comprehension of texts containing unknown vocabulary items. 63 intermediate EFL learners were given Honey's (2004) appraisal test, Connor and Davidson's (2003) Resilience Scale, a vocabulary checklist, and a validated battery of four reading tests.

Results showed that (a) the levels of critical thinking had a significant effect on the scores of the participants on the resilience scale, (b) the levels of critical thinking had significant effect on the participants' comprehension of texts with unfamiliar vocabulary items, and (c) the levels of resilience had significant effect on the participants' comprehension of texts with unfamiliar vocabulary items.

\section{Critical Reading}

With regard to the similarity between critical reading and critical thinking, Thistlethwaite (1990) points out that critical thinking skills frequently listed in textbooks for teaching critical thinking are similar to, or perhaps the same as those listed in reading texts described as critical reading skills (p.587). For example, critical thinking skills such as withholding judgment until confirming or disconfirming evidence is gathered, questioning, being flexible, inferring, predicting outcomes and recognizing bias are some of the skills that can also be found in critical reading textbooks (Sherbourne, 1981).

Commeyras (1990) also raises this issue. She states that "The claim that critical thinking is closely related to reading comprehension is similar to the view that reasoning is an integral part of reading. Critical thinking, which involves reasoning, is the process the reader uses to determine which interpretations are consistent with textual evidence and background knowledge" (p.201). This view is also supported by Colins, Brown and Larkin (1980).

A research project on measuring high-school students' level of critical reading skills and identifying the relationship (if any) between students' critical reading levels and critical thinking dispositions and reading frequency in both English and Turkish was done by Isik (2010). Data were gathered through two scales, namely, Critical Reading Scale and California Critical Thinking Dispositions Inventory. The results revealed a positive and direct correlation, though not significant, between the students' critical reading levels and their critical thinking dispositions. Regarding the relationship between the students' 
critical reading levels and reading frequency, the findings showed no relationship between these two variables.

Elder and Paul (2006) claim that critical thinking is important in the acquisition of language skills, particularly reading. Several studies confirm that critical thinking is related to language learning in general and reading comprehension, in particular. For example, a research was conducted on the relationship between the critical thinking ability of test takers and their performance on the reading section of PBT (paper-based TOEFL). The results indicated a positive, high correlation between the two variables. The researcher finally mentioned some implications regarding MDI (MeasurementDriven Instruction) reading courses which aimed at providing learners with some handy strategies to boost their performance on high stakes language proficiency tests (Fahim, Bagherkazemi \& Alemi, 2010).

Similarly, Boloori (2010) conducted a study to evaluate the predictive power of critical thinking of Iranian English language learners on their performance on inferential reading comprehension tests. She found a significant correlation between critical thinking and inferential reading comprehension. In another study, Kamali and Fahim (2011) reported a significant relationship between critical thinking and reading abilities of learners. According to them, critical thinking is a strong predictor of learners' achievement. Fahim and Saeepour (2011) investigated the impact of teaching critical thinking skills on reading comprehension of Iranian EFL learners. Using debate in the classroom as a kind of critical thinking activity, the researchers administered a validated reading comprehension test and a standard critical thinking appraisal test to the participants. The results showed that teaching critical thinking skills could enhance readers' reading comprehension ability. The reverse order is also true; Gomez (2010) reported that students who received structured reading lessons had better performance on critical thinking skills test in comparison with those who received traditional reading instruction.

But Aleger (1993), in his study on the effects of thinking skills on students' reading comprehension, found that all students experienced significant gains in reading comprehension, but no statistical differences were found between experimental and control groups.

\section{Foreign Language Reading Anxiety}

In one of the pioneering studies on FLRA, Saito, Garza, and Horwitz (1999) investigated FLRA among learners of Japanese, French and Russian. To explore this construct, Saito et al. (1999) used the Foreign Language Classroom Anxiety Scale (FLCAS), measuring language anxiety related to various aspects of foreign language learning, and Foreign Language Reading Anxiety Scale (FLRAS), eliciting reading anxiety, to examine native English speakers of 192 French, 114 Japanese, and 77 Russian learners. In their study, two aspects of foreign language reading were investigated which had great effect on eliciting anxiety: unfamiliar scripts of writing systems and unfamiliar cultural materials (p. 203). They found that despite the intuition of teachers, reading in a foreign language is anxiety provoking for some students. 
Moreover, Saito et al. (1999) concluded that FLRA was a phenomenon related to, but distinct from, general FL anxiety. They pointed out that reading was anxiety provoking to some foreign language learners although participants in general reported slightly less reading anxiety than general foreign language anxiety. It was also found that increasing students' reading anxiety levels leads to the decrease of students' final grades.

In a study, Lien (2011) attempted to investigate EFL learners' reading strategy use in relation to reading anxiety. One hundred and eight EFL freshmen participated in this study and three instruments were administered to them: a questionnaire to investigate the background and reading habits of the participants, the Foreign Language Reading Anxiety Scale to investigate the participants' reading anxiety, and the Survey of Reading Strategies to investigate the participants' extensive reading strategies use. A negative correlation was found between reading anxiety and reading strategies.

Regarding the correlation between anxiety and critical thinking, it is inferred that anxiety leads the individual to mental disruption and prevents him or her from high level thinking; therefore, it can disrupt critical thinking (Broadbear, 2005). In a similar study, Fahim (2014) found a significant negative correlation between foreign language anxiety and critical thinking.

\section{METHOD}

\section{Participants}

To meet the purpose of this study, 260 volunteer learners took part in the study aging 18-22. They were studying English at Khatam ol-Anbia University in Tehran, Iran. The mother tongue of the participants was Farsi, and they were at intermediate proficiency level according their scores obtained from proficiency test. The Michigan Test of English Language Proficiency (MTELP) was administered to homogenize the participants in terms of their level of proficiency. After the administration of the MTELP, 83 of the learners were excluded due to extreme scores. Ultimately, with regard to the results of the proficiency test, 177 out of 260 were selected.

\section{Instruments}

The following four instruments were used for the purpose of this study:

I. Michigan Test of English Language Proficiency (MTELP):

In order to obtain a homogeneous group, the MTELP as a general proficiency test was administered for controlling the learners in terms of their language proficiency level prior to the experiment. The 100-item multiple-choice test has three parts, containing 40 grammar items, 40 vocabulary items, and reading passages followed by 20 comprehension questions.

- $\quad$ California Critical Thinking Skills Test (CCTST-B-34):

An English version of the CCTST-Form B was used to determine the participants' critical thinking skills. This test contains 34 multiple choice items with only one true answer. Each item is followed by four or five alternatives with 5 subscales checking 
respondents' analysis, evaluation, inference, deductive reasoning, and inductive reasoning (Erwin,2000). Six types of scores are obtained from the CCTST: an overall score, and five sub-scales scores (analysis, evaluation, inference, deductive reasoning, and inductive reasoning), and the highest score is 34 . It should be stated that for answering these questions, participants do not need to possess knowledge in a specific area.

The test developers believe that the CCTST has been designed on some general knowledge, developing gradually in the process of natural maturation. The test items cover different topics, with most questions combining content with reasoning. CCTST is a standard test which is being extensively used in most studies in the fields of Education and Psychology. According to the questionnaire manual, participants should complete the test in 45 minutes.

Many studies have used California Critical Thinking Skills Test, and its reliability and validity have been checked several times. Facione and Facione (1994) estimated the reliability of the test and found it acceptable $(\alpha=.70-.71)$. There have been a number of other studies in the Iranian context which have approved the reliability of CCTST at a considerably positive level (Khalili \& Hossein Zadeh, 2003; Babamohammady \& Khalili, 2004). Khalili.et al. (2003) reported that the reliability index of the scale was 0.62 , and the construct validity of all subscales was between $0.60-0.65$ with highly positive correlation. In this study, Cronbach's alpha coefficients turned to be 0.81 .

\section{- $\quad$ Critical Reading Scale (CRS):}

Zhou, Jiang and Yao (2015) designed the questionnaire on the basis of Facione's List of Core Six CT Skills (1991). The questionnaire on CT Ability in English Reading is composed of the following two main parts, concerning the participants' personal background information (gender, major, grade) and their CT abilities.

The second part has a Likert-type scale (5=agree; 4=basically agree; 3 =hard to say; $2=$ not quite agree; $1=$ disagree) and allows students to describe their routine reading behavior.

\section{- Foreign Language Reading Anxiety Scale (FLRAS):}

It was developed by Saito et al. (1999) to "elicit students' self-reports of anxiety over various aspects of reading, their perceptions of reading in their target language, and their perceptions of the relative difficulty of reading as compared to other language skills" ( $p$. 204). The scale is a self-report with 20 Likert-type items scored on a 5-point scale, ranging from strongly disagrees to strongly agree. The possible range of scores in the FLRAS is from 20 to 100 , and the lower scores in the FLRAS indicate lower levels of reading anxiety.

No pilot study of FLRAS was made because reading anxiety has shown high internal reliability and high validity across studies (Wang, 2010). Saito.et al. (1999) reported an alpha coefficient of .86 for internal consistency in the FLRAS. The reliability of reading 
anxiety questionnaire was re-estimated in the context of this study, and the alpha coefficient turned out to be .93 .

\section{Data Collection Procedure and Analysis}

From a total of 260 learners, approximately $66 \%$ of the total number of learners was selected to participate in the study. 83 participants were excluded from the study because of high or low levels of proficiency measured through the Michigan Test.

To achieve the purpose of the study, the following procedure was followed. At the first stage, the participants were explained about the study procedure. Next, the MTELP was given to the participants in order to homogenize the participants. They had 45 minutes to complete this test. Only the intermediate students were remained in the research and students with extreme scores were removed. Then, the critical reading and critical listening scales were administered. In the next stage, the reading anxiety scale and listening anxiety scale were given to the same participants in their original version. In all stages, if the participants have questions, the researcher answered them. The obtained data were submitted to statistical analysis.

\section{FINDINGS}

\section{Ensuring the Reliability of the Research Instruments}

Tables 1 and 2 show the descriptive statistics of Michigan test and California Critical Thinking Skills Scale.

Table 1

Descriptive Statistics of Michigan Test of English Language Proficiency

\begin{tabular}{llllll}
\hline $\mathrm{N}$ & Mean & Std. deviation & Variance & Minimum & Maximum \\
\hline 177 & 60.47 & 7.39 & 82.56 & 43 & 82 \\
\hline
\end{tabular}

Table 2

Descriptive Statistics of California Critical Thinking Skills Scale

\begin{tabular}{lllllll}
\hline & $\mathrm{N}$ & Minimum & Maximum & Sum & Mean & Std. Deviation \\
\hline Analysis & 177 & 1 & 10 & 1102 & 5.011 & 2.485 \\
\hline Evaluation & 177 & 1 & 15 & 1387 & 6.928 & 3.298 \\
\hline Inference & 177 & 0 & 10 & 1199 & 5.867 & 2.488 \\
\hline Deduction & 177 & 2 & 17 & 1490 & 7.493 & 3.471 \\
\hline Induction & 177 & 2 & 11 & 1577 & 8.045 & 2.402 \\
\hline Valid N (list wise) & 177 & & & & & \\
\hline
\end{tabular}

In order to compute the reliability of instruments several procedures were used. As Table 3 shows, KR-21 was used for calculating the reliability of MTELP, and Cronbach's Alpha was used for Critical Thinking Skills Test, Critical Reading Questionnaire, and Foreign Reading Anxiety Questionnaire. 
Table 3

Reliability Statistics of Reading Anxiety Questionnaire

\begin{tabular}{lll}
\hline Instrument & Statistical Procedure & Result \\
\hline Michigan Test of English Language Proficiency (MTELP) & KR-21 & .937 \\
California Critical Thinking Skills Test (CCTST) & Chronbach's Alpha & .813 \\
Critical Reading Questionnaire & Chronbach's Alpha & .911 \\
Foreign Reading Anxiety Questionnaire & Chronbach's Alpha & .933 \\
\hline
\end{tabular}

\section{The First Research Question}

In the first research question, the researchers sought to explore which subscale of critical thinking skills was a stronger predictor of EFL learners' critical reading. According to the results of the model summary (Table 4), analysis shared about 5\%, analysis and evaluation $15 \%$, analysis, evaluation and inference $17 \%$, analysis, evaluation, inference, and deduction $22 \%$, and analysis, evaluation, inference, deduction, and induction collectively account for about $23 \%$ of the variance with critical reading.

Table 4

Results of the Model Summary

\begin{tabular}{llll}
\hline Model & R & R Square & Adjusted R Square \\
\hline 1 & $.249 \mathrm{a}$ & .060 & .054 \\
2 & $.398 \mathrm{~b}$ & .162 & .153 \\
3 & $.463 \mathrm{c}$ & .211 & .179 \\
4 & $.502 \mathrm{~d}$ & .235 & .221 \\
5 & $.499 \mathrm{e}$ & .271 & .239 \\
\hline
\end{tabular}

a. Predictors: (Constant), Analysis

b. Predictors: (Constant), Analysis, Evaluation

c. Predictors: (Constant), Analysis, Evaluation, Inference

d. Predictors: (Constant), Analysis, Evaluation, Inference, Deduction

e. Predictors: (Constant), Analysis, Evaluation, Inference, Deduction, Induction

Table 5 gives the results of the ANOVA performed on the models. The F-value and significance levels indicate that all the five models are statistically significant. The results show that the predictive power of the models is significant. 
Table. 5

Results of ANOVAa Performed on the Models

\begin{tabular}{|c|c|c|c|c|c|c|}
\hline Model & & $\begin{array}{l}\text { Sum of Squ } \\
\text { ares }\end{array}$ & df & $\begin{array}{l}\text { Mean Squar } \\
\mathrm{e}\end{array}$ & $\mathrm{F}$ & Sig. \\
\hline & Regression & 7382.394 & 1 & 4075.232 & 12.276 & $.001 \mathrm{~b}$ \\
\hline \multirow[t]{3}{*}{1} & Residual & 60798.321 & 175 & 312.144 & & \\
\hline & Total & 68180.715 & 176 & & & \\
\hline & Regression & 12398.283 & 2 & 5580.171 & 18.113 & $.000 \mathrm{c}$ \\
\hline \multirow[t]{3}{*}{2} & Residual & 55782.432 & 174 & 312.382 & & \\
\hline & Total & 68180.715 & 176 & & & \\
\hline & Regression & 13589.355 & 3 & 4822.211 & 16.967 & $.000 \mathrm{~d}$ \\
\hline \multirow[t]{3}{*}{3} & Residual & 54591.360 & 173 & 280.419 & & \\
\hline & Total & 68180.715 & 176 & & & \\
\hline & Regression & 17216.688 & 4 & 4064.916 & 14.456 & $.000 \mathrm{e}$ \\
\hline \multirow[t]{2}{*}{4} & Residual & 50964.047 & 172 & 257.284 & & \\
\hline & Total & 68180.715 & 176 & & & \\
\hline \multirow[t]{3}{*}{5} & Regression & 16944.594 & 5 & 3427.747 & 14.635 & $.000 \mathrm{f}$ \\
\hline & Residual & 51236.121 & 171 & 268.464 & & \\
\hline & Total & 68180.715 & 176 & & & \\
\hline
\end{tabular}

a. Dependent Variable: CR

b. Predictors: (Constant), Analysis

c. Predictors: (Constant), Analysis, Evaluation

d. Predictors: (Constant), Analysis, Evaluation, Inference

e. Predictors: (Constant), Analysis, Evaluation, Inference, Deduction

f. Predictors: (Constant), Analysis, Evaluation, Inference, Deduction, Induction

To see how much of the variance in critical reading is accounted for by each of the five predictors, the standard coefficients and the significance of the observed t-value for each predictor was checked. Table 6 shows that for every one standard deviation (SD) of change in one's analysis, there will be about .23 of a SD change in ones' critical reading. In model two, when analysis and evaluation are taken together, for every one standard deviation of change in one's analysis and evaluation, there will be .18 and .33 of a standard deviation change in one's critical reading, respectively. In model three, when analysis, evaluation, and inference are taken together, for every one SD change in one's analysis, evaluation, and inference, there will be $.17, .30$, and .23 of a SD change in one's critical reading, respectively. In model four, when analysis, evaluation, inference, and deduction are taken together, for every one SD change in one's analysis, evaluation, inference, and deduction, there will be $.13, .31, .20$, and .15 of a SD change in one's critical reading, respectively. In model five, when analysis, evaluation, inference, deduction, and induction are taken together, for every one SD change in one's analysis, evaluation, inference, deduction, and induction, there will be $.6, .29, .22, .16$, and .22 of a SD change in one's critical reading, respectively. The relationship between these variables and critical reading is positive. This means that as one's subscales of critical thinking skills improve; his/her critical reading also increases. But in the cases that the Beta value is greater than .05 (analysis in model four, analysis and deduction in model five), they are not statistically significant. 
Table 6

Standard Coefficients and the Significance of the Observed T-Value

\begin{tabular}{|c|c|c|c|c|c|c|}
\hline \multirow[t]{2}{*}{ Model } & & \multicolumn{2}{|c|}{ Unstandardized Coefficients } & \multirow{2}{*}{$\begin{array}{l}\text { Standardized } \\
\text { Coefficients } \\
\text { Beta }\end{array}$} & \multirow[t]{2}{*}{$\mathrm{t}$} & \multirow[t]{2}{*}{ Sig. } \\
\hline & & $\mathrm{B}$ & Std. Error & & & \\
\hline \multirow[t]{2}{*}{1} & (Constant) & 49.926 & 2.819 & & 19.418 & .000 \\
\hline & Analysis & .161 & .045 & .240 & 3.512 & .001 \\
\hline \multirow[t]{3}{*}{2} & (Constant) & 41.734 & 3.380 & & 11.337 & .000 \\
\hline & Analysis & .127 & .044 & .179 & 2.433 & .009 \\
\hline & Evaluation & .231 & .051 & .325 & 4.872 & .000 \\
\hline \multirow[t]{4}{*}{3} & (Constant) & 34.423 & 4.085 & .182 & 8.157 & .000 \\
\hline & Analysis & .107 & .043 & .311 & 2.402 & .017 \\
\hline & Evaluation & .248 & .050 & .235 & 4.901 & .000 \\
\hline & Inference & .197 & .051 & & 3.431 & .001 \\
\hline \multirow[t]{5}{*}{4} & (Constant) & 30.546 & 4.662 & & 6.796 & .000 \\
\hline & Analysis & .444 & .064 & .132 & 1.761 & .080 \\
\hline & Evaluation & .235 & .060 & .313 & 4.534 & .000 \\
\hline & Inference & .177 & .052 & .206 & 3.282 & .001 \\
\hline & Deduction & .147 & .054 & .158 & 2.352 & .020 \\
\hline \multirow[t]{6}{*}{5} & (Constant) & 21.549 & 5.002 & & 4.545 & .000 \\
\hline & Analysis & .041 & .042 & .065 & .672 & .502 \\
\hline & Evaluation & .210 & .051 & .291 & 4.515 & .000 \\
\hline & Inference & .186 & .051 & .226 & 3.089 & .002 \\
\hline & Deduction & .167 & .060 & .164 & 1.842 & .067 \\
\hline & Induction & .201 & .071 & .224 & 2.771 & .006 \\
\hline
\end{tabular}

\section{The Second Research Question}

The aim of the second research question was to investigate to what extent critical thinking skills can predict foreign language reading anxiety. Model summary (Table 7) shows that analysis shared about $8 \%$, analysis and evaluation for $13 \%$, analysis, evaluation and inference $14 \%$, analysis, evaluation, inference, and deduction $27 \%$, and analysis, evaluation, inference, deduction, and induction collectively account for about $33 \%$ of the variance with foreign language reading anxiety.

Table 7

Model Summary of Critical Thinking Skills

\begin{tabular}{llll}
\hline Model & R & R Square & Adjusted R Square \\
\hline 1 & $.291 \mathrm{a}$ & .081 & .089 \\
2 & $.345 \mathrm{~b}$ & .136 & .133 \\
3 & $.403 \mathrm{c}$ & .149 & .140 \\
4 & $.542 \mathrm{~d}$ & .281 & .275 \\
5 & $.584 \mathrm{e}$ & .319 & .332 \\
\hline
\end{tabular}

Table 8 gives the results of the ANOVA performed on the models. The F-value and significance levels indicate that all the five models are statistically significant. The results show that the predictive power of all the models is significant. 
Table 8

Results of ANOVAa Performed on the Models

\begin{tabular}{lllllll}
\hline Model & & Sum of Squares & df & Mean Square & F & Sig. \\
\hline 1 & Regression & 6819.376 & 1 & 5627.375 & 16.772 & $.000 \mathrm{~b}$ \\
& Residual & 73339.835 & 175 & 380.603 & & \\
\multirow{2}{*}{2} & Total & 80159.211 & 176 & & & $.000 \mathrm{c}$ \\
& Regression & 8896.487 & 2 & 4647.265 & 13.438 & \\
\multirow{3}{*}{3} & Residual & 71262.724 & 174 & 336.464 & & $.000 \mathrm{~d}$ \\
& Total & 80159.211 & 176 & & & \\
& Regression & 12133.766 & 3 & 3946.321 & 12.754 & $.000 \mathrm{e}$ \\
4 & Residual & 68025.445 & 173 & 332.973 & & \\
& Total & 80159.211 & 176 & & & \\
& Regression & 24224.368 & 4 & 4977.198 & & \\
& Residual & 55934.843 & 172 & 288.856 & & \\
& Total & 80159.211 & 176 & & & \\
& Regression & 20043.878 & 5 & 5312.234 & & \\
& Residual & 54115.333 & 171 & 263.653 & & \\
& Total & 80159.211 & 176 & & & \\
\hline
\end{tabular}

a. Dependent Variable: Foreign Language Reading Anxiety

b. Predictors: (Constant), Analysis

c. Predictors: (Constant), Analysis, Evaluation

d. Predictors: (Constant), Analysis, Evaluation, Inference

e. Predictors: (Constant), Analysis, Evaluation, Inference, Deduction

f. Predictors: (Constant), Analysis, Evaluation, Inference, Deduction, Induction

To see how much of the variance in foreign language reading anxiety is accounted for by each of the five predictors, the standard coefficients and the significance of the observed t-value for each predictor was checked. Table 9 shows that for every one standard deviation (SD) of change in one's analysis, there will be about .26 of a SD change in ones' FLRA. In model two, when analysis and evaluation are taken together, for every one standard deviation of change in one's analysis and evaluation, there will be .25 and .21 of a standard deviation change in one's FLRA, respectively. In model three, when analysis, evaluation, and inference are taken together, for every one SD change in one's analysis, evaluation, and inference, there will be $.22, .20$, and .23 of a SD change in one's FLRA, respectively. In model four, when analysis, evaluation, inference, and deduction are taken together, for every one SD change in one's analysis, evaluation, inference, and deduction, there will be $.12, .16, .19$, and .35 of a SD change in one's FLRA, respectively. In model five, when analysis, evaluation, inference, deduction, and induction are taken together, for every one SD change in one's analysis, evaluation, inference, deduction, and induction, there will be $.03, .15, .16, .30$, and .22 of a SD change in one's FLRA, respectively. The relationship between these variables and FLRA is negative.

This means that as one's subscales of critical thinking skills improve, his/her reading anxiety decreases. But in the cases that the Beta value is greater than .05 (analysis in model four, analysis in model five), they are not statistically significant. 
Table 9

Standard Coefficients and the Significance of the Observed T-Value for Each Predictor

\begin{tabular}{|c|c|c|c|c|c|c|}
\hline \multirow[t]{2}{*}{ Model } & & \multicolumn{2}{|c|}{ Unstandardized Coefficients } & \multirow{2}{*}{$\begin{array}{l}\text { Standardized } \\
\text { Coefficients } \\
\text { Beta }\end{array}$} & \multirow[t]{2}{*}{$\mathrm{t}$} & \multirow[t]{2}{*}{ Sig. } \\
\hline & & $\mathrm{B}$ & Std. Error & & & \\
\hline \multirow[t]{2}{*}{1} & (Constant) & 70.566 & 3.234 & & 25.649 & .000 \\
\hline & Analysis & -.234 & .054 & -.269 & -3.545 & .000 \\
\hline \multirow[t]{3}{*}{2} & (Constant) & 79.415 & 3.644 & & 20.850 & .000 \\
\hline & Analysis & -.156 & .038 & -.254 & -3.474 & .001 \\
\hline & Evaluation & -.157 & .067 & -.215 & -2.124 & .004 \\
\hline \multirow[t]{4}{*}{3} & (Constant) & 85.720 & 4.658 & & 18.454 & .000 \\
\hline & Analysis & -.151 & .086 & -.224 & -3.677 & .002 \\
\hline & Evaluation & -.153 & .046 & -.201 & -2.754 & .007 \\
\hline & Inference & -.177 & .043 & -.238 & -3.466 & .002 \\
\hline \multirow[t]{5}{*}{4} & (Constant) & 94.433 & 4.544 & & 20.754 & .000 \\
\hline & Analysis & -.053 & .065 & -.126 & -1.653 & .071 \\
\hline & Evaluation & -.140 & .072 & -.161 & -2.433 & .022 \\
\hline & Inference & -.144 & .033 & -.196 & -2.654 & .004 \\
\hline & Deduction & -.346 & .064 & -.354 & -5.367 & .000 \\
\hline \multirow[t]{6}{*}{5} & (Constant) & 102.432 & 5.164 & & 20.754 & .000 \\
\hline & Analysis & -.024 & .057 & -.034 & -.432 & .664 \\
\hline & Evaluation & -.233 & .053 & -.154 & -2.356 & .025 \\
\hline & Inference & -.143 & .042 & -.162 & -2.575 & .009 \\
\hline & Deduction & -.345 & .050 & -.302 & -5.456 & .000 \\
\hline & Induction & -.253 & .042 & -.223 & -3.644 & .000 \\
\hline
\end{tabular}

\section{DISCUSSION}

Based on the findings of this study, all the five subscales of critical thinking skills were predictors of critical reading and foreign language reading anxiety. Based on these results, it can be concluded that if we want to enhance EFL learners' critical reading level or decrease their anxiety, their critical thinking skills should be improved. It was revealed that evaluation had the most significant (positive) contribution to the prediction of critical reading. In the same way, deduction and induction had the most significant (negative) contribution to reading anxiety.

As the first finding of this study showed, critical thinking skills can predict critical reading. This result is in line with some previous studies. For example, Elder and Paul (2006) claimed critical thinking is important in the learning of reading skills. Boloori (2010) found a significant correlation between critical thinking and reading comprehension. Fahim, Bagherkazemi, and Alemi (2010) also concluded that test takers with higher critical thinking abilities showed better performance on the reading comprehension section of TOEFL. Isik (2010) showed a direct positive correlation between the students' critical reading levels and their critical thinking dispositions. Kamali and Fahim (2011) reported levels of critical thinking had a significant effect on the participants' comprehension of texts. Similarly, Fahim and Saeepour (2011) showed that teaching critical thinking skills could enhance readers' reading comprehension ability. 
Based on the relationship between CTS and CR, Thistlethwaite (1990) and Sherbourne (1981) point out that critical thinking skills are similar to, or perhaps the same as, critical reading skills (p. 587). Commeyras (1990) and Colins, Brown, and Larkin (1980) are of similar opinion. They state that critical thinking is closely related to reading comprehension and that reasoning is an integral part of reading.

However, these findings do not corroborate those of Aleger (1993), who found that all students experienced significant gains in reading comprehension; no statistical differences were found to exist between experimental and control groups.

Furthermore, the findings of the present study about the predictive power of CTS and FLRA lend support to those of Hsu (2004) and Lien (2011). Hsu (2004) explored reading anxiety and reading comprehension of college EFL students and found that anxious students tended to recall less content than less anxious students.

Regarding the meaningful correlation between anxiety and critical thinking, Broadbear (2005) asserted that anxiety leads the individual to mental disruption and prevents him or her from high level thinking; therefore, it can disrupt critical thinking. Barkhordari, et al. (2011) also supported the negative correlation between gravitation to critical thinking and anxiety.

\section{CONCLUSION}

Based on the findings of two research questions in this study, all the five subscales of critical thinking skills were good predictors of critical reading, and foreign language reading anxiety. Therefore, teachers and learners should consider all skills comprehensively and do not exclude or insist in each skill. Critical thinking skills are complex, and it is crucial that they be introduced in the first years of education and further refined over the course of the program. "Critical thinking is more than the successful use of the right skill in an appropriate context. It is also an attitude or disposition to recognize when a skill is needed and the willingness to exert the mental effort needed to apply it" (Halpern, 2000, p. 72).

The teaching of critical thinking is a complex endeavor even in normal circumstances. If teaching critical thinking remains a course goal, multiple opportunities to practice each skill should be included to increase the probability of a significant improvement in all skills. This may mean reducing the number of faculty involved and spending more time on each issue covered.

\section{IMPLICATIONS}

The findings of this study might be useful for EFL teachers and learners, material developers, and syllabus designers. Once teachers grasp the concept and value of critical thinking skills development in their classrooms, they will begin to see opportunities all around them for encouraging their students in this area. Most experienced teachers recognize that the more you know about the backgrounds and interests of your students, the more appropriate and engaging your classes will become. This element is even more significant for classes with a focus on critical thinking. Although it is true that an experienced teacher can create a critical thinking atmosphere 
in almost any lesson, it is not true that students will respond to various lessons or topics equally well. Consider as an example a grammatical unit on the use of the future tense. A teacher wishing to help promote critical thought in their class might ask a series of discussion questions on the ethical issues surrounding future increases in life expectancy. This lesson could be highly successful if it is appropriate to the students' age level, background knowledge, and language proficiency. More appropriate questions could certainly be found for an ESP Engineering class or for a group of 12-13 year-old boys and girls. The point is that tailoring lessons specifically to the interests of your students can go quite far in encouraging student engagement, an element that is essential to the development of critical thinking (Halvorsen, 2005).

Meanwhile, the findings of the present study may have implications for learners. Learners should be given more opportunities to develop their critical thinking in the process of language learning. For promoting critical reading, using tasks as a way to make readers engaged, care should be taken to consider these tasks as "uniquely situated, emergent interactions based on participants' goals and not merely task objectives and invariant task procedures" (Lantolf, 2000, p. 44). The use of critical thinking would assist EFL learners to work better in learning a foreign language. In order to perform properly in society, and develop independent learning, individuals must be able to think critically and reason effectively.

\section{REFERENCES}

Aleger, A. (1993). The Direct teaching of thinking skills for improvement of reading comprehension skills, Published Dissertation, Drake University, Singapore.

Anderson, N. J. (2003). Metacognitive reading strategies increase L2 performance. The Language Teacher Online, 27(7), 1-3.

Astleitner, H. (2007). Teaching critical thinking online. Journal of Instructional Psychology, 29(2), 53-77.

Atkinson, D. (1997). A critical approach to critical thinking in TESOL. TESOL Quarterly, 31(1), 71-94.

Barkhordari, M., Jalalmanesh, Sh., \& Mahmoudi, M. (2011). Evaluation of the level of gravitation to critical thinking in BS nursing students in university of medical sciences and health and treatment centers of Shahid Sadoughi and Azad Islamic University of the city of Yazd. Iran Nursing Journal, 69, 18-25.

Boloori, L. (2010). The relationship between critical thinking and performance of Iranian EFL learners on the inferential reading comprehension test (Unpublished master's thesis). Azad University of Takestan, Iran.

Broadbear, J. T., Guang, J., \& Bierma, T. J., (2005). Critical thinking dispositions among undergraduate students during their introductory health education course. Health Educator, 37(1), 8-15. 
Carrell, P.L., \& Grabe, W. (2002). Reading. In: N. Schmitt (Eds), An introduction to applied Linguistics (pp. 233-250). Oxford: Oxford University Press.

Chang, F. R. (1983). Mental processes in reading: A methodological review. Reading Research Quarterly, 216-130.

Colins, A., Brown, J. S., \& Larkin, K. M. (1980). Inference in text understanding. In R. J. Spiro, B. C. Bruce, \& W. F. Brewer (Eds), Theoretical issues in reading comprehension (pp. 385-407). Hillsdale, NJ: Lawrence Earlbaum Associates, Inc.

Commeyras, M. (1990). Analyzing a critical-thinking reading lesson. Teaching and Teacher Education. 6(3), 201-214.

Crystal, D. (2007). How language works: How babies babble, words change meaning, and languages live or die. USA: Avery Pub Group.

Ennis, R. (1996). Critical thinking assessment. Theory into Practice, 32(3), 179-186.

Erwin, T. D. (2000). The NPEC source book on assessment: definitions and assessment method for critical thinking problem solving, and writing. Washington, DC: US. Government Printing Office. \#2: Purposes for Listening

Facione, P. A., \& Facione, N. C. (1994). The California critical thinking skills test: Test manual. Millbrae, CA: California Academic Press.

Fahim, M. (2014). The relationship between critical thinking and foreign language anxiety. International Journal of Language Learning and Applied Linguistics World (IJLLALW), 5(3), 136-148.

Fahim, M., \& Kamali, Z. (2011). The relationship between critical thinking ability of Iranian EFL Learners and their resilience level facing unfamiliar vocabulary items in reading. Journal of Language Teaching and Research, 2(1), 101-114.

Fahim, M., \& Saeepour, M. (2011). The impact of teaching critical thinking skills on reading Comprehension of Iranian EFL learners. Journal of Language Teaching and Research, 2(4), 867-74.

Fahim, M., Bagherkazemi, M., \& Alemi, M. (2010). The relationship between test takers' critical thinking ability and their performance on the reading section of TOEFL. Journal of Language Teaching and Research, 1(6), 830-837.

Flemming, L. E. (2011). Reading for thinking. (7th Ed.). Boston: Houghton Mifflin Company.

Fox, H. (1994). Listening to the world: Cultural issues in academic writing. U.S.A: National Council of Teachers of English.

Freebody, P., \& Luke, A. (1990). 'Literacies' programs: Debates and demands in cultural Context. Prospect, 5(3), 7-16. 
Freese, A. (1997). Reading rate and comprehension: Implications for designing computer Technology to facilitate reading comprehension. Computer Assisted Language Learning, 10(4), 311-319.

Giancarlo, C. A., \& Facione, P. A. (2001). A look across four years at the disposition towards Critical thinking among undergraduate students. The Journal of General Education, 50(1), 29-55.

Grabe, W., \& Stoller, F.L. (2001). Reading for academic purpose: Guidelines for ESL/EFL Teachers. In: M. Celce-Murcia (Eds), Teaching English as a second or foreign language (pp. 187-203). US: Heinle \& Heinle.

Hale, S. (2008). A critical analysis of Richard Paul's Substantive Tran-disciplinary conception of critical thinking (Unpublished doctoral dissertation). Union University of Cincinnati, Ohio.

Halpern, D. F. (2000). Teaching for critical thinking: helping college students develop the skills and dispositions of a critical thinker. In M. D. Svinicki (Eds), Teaching and learning on the edge of the millennium: Building on what we have learned. New directions for teaching and learning (pp. 69-74). San Francisco, CA: Jossey-Bass.

Halvorsen, A. (2005). Incorporating critical thinking skills development into ESL/EFL courses. The Internet TESL Journal, 11(3), 1-5.

Hsu, Y.C. (2004). A study on junior college students' reading anxiety in English as a foreign language (Unpublished master's thesis). National Chung Cheng University, Chiayi, Taiwan.

Huijie, L. (2010). Developing a hierarchical framework of critical reading proficiency. Chinese Journal of Applied Linguistics, 33, 40-54.

Isik, H., (2010). High school students' critical reading levels and the relationship between critical reading level and critical thinking dispositions and proficiency (Unpublished master's thesis). Anadolu University, Turkey.

Jacobs, S. S. (1995). Technical characteristics and some correlates of the California critical thinking skills test forms A and B. Higher Education Research, 36, 89-108.

Khalili, H. \& Hosseinzadeh, M. (2003). Investigation of reliability, validity and normality Persian version of the California critical thinking skills test: Forum B (CCTST). Journal of Medical Education 3(1), 29-32.

Khalili, H., \& Babamohamadi, H. (2004). The critical thinking skills of nursing students in the Semnan university of Medical sciences. Journal of Education in Medical Sciences, 4(12), 23-31.

Lantolf, J. P. (2000). Sociocultural theory and second language learning. Oxford: Oxford University Press.

Lien, H. Y. (2011). EFL learners' reading strategy use in relation to reading anxiety. Language Education in Asia, 2(2), 2011. 
Lightbown, Patsy, M., \& Spada, N. (2013). How languages are learned. Oxford: Oxford University Press.

Mason, M. (2007). Critical thinking and learning. Educational Philosophy and Theory, 39(4), 337-473.

Millan, D. (1995). Developing reading skills. New York: McGraw-Hill, Inc.

Na, Z. (2007). A study of high school students' English learning anxiety. Asian EFL Journal, 9(3), 22-34.

Paul, R., \& Elder, L. (2002). Critical thinking: Tools for taking charge of your professional and personal life. Dillon Beach, CA: Foundation for Critical Thinking.

Paul, R., \& Elder, L. (2005). A guide for educators to critical thinking competency standards. Dillon Beach, CA: Foundation for critical thinking.

Paul, R., \& Elder, L. (2006). Critical thinking: The nature of critical and creative thought. Journal of Developmental Education, 30(2), 34-35.

Pirozzi, R. (2003). Critical reading, critical thinking (2nd ed.). New York. Longman.

Rashid, R. A., \& Hashim, R. A. (2008). The Relationship between critical thinking and language proficiency of Malaysian and undergraduates. Proceeding of the EDUCOM 2008 International Conference, Symposia and Campus Events, 19-21 November 2008, Edith Cowan University, Perth Western Australia.

Rayner, K., Foorman, B., Perfetti, C., Pesetsky, D., \& Seidenberg, M. (2001). How psychological science informs the teaching of reading. Psychological Science in the Public Interest, 31-74.

Saito, Y., Horwitz, E. K., \& Garza, T. J. (1999). Foreign language reading anxiety. Modern Language Journal, 83(2), 202-218.

Schwegler, R. (2004). Patterns of exposition (17th Ed.). London: Person Education, Inc.

Sherbourne, J. F. (1981). Toward reading comprehension. Lexington, MA: Heath. Thistlethwaite,

L. L. (1990). Critical reading for at-risk students. Journal of Reading, 33(8), 586-593.

Villavicencio, F. T. (2011). Critical thinking, negative academic emotions, and achievement: A meditational analysis. The Asia Pacific Education Researcher, 20(1), 118-126

Wang, S. (2010). An experimental study of Chinese English major students' listening anxiety of classroom learning activity at the university level. Journal of Language Teaching and Research, 1, 562-568.

Wei, M. (2007). The interrelatedness of affective factors in EFL learning: An examination of motivational patterns in relation to anxiety in China. TESL-EJ, 11(1), 123. 
Weiler, A. (2004). Information-seeking behavior in generation Y students: Motivation, critical thinking, and learning theory. The Journal of Academic Librarianship, 31(1), 46-53.

Yeh, Y., \& Wu, J. (1992). The relationship between critical thinking and academic achievement among elementary and secondary school students. Journal of Education and Psychology, 15, 79-100.

Zhou, J., Jiang, Y., \& Yao, Y. (2015). The investigation on critical thinking ability in EFL reading class. English Language Teaching, 8(1), 84-93. 